\title{
The Roles of Farmers in the Development of Belimbing Village Agrotourism and Its Effect on Satisfaction and Loyalty of Tourists
}

\author{
Ni Nyoman Widari ${ }^{1}$, I Gusti Ayu Oka Suryawardani², \\ I Ketut Rantau ${ }^{1}$ and Agung Suryawan Wiranatha ${ }^{2}$ \\ ${ }^{1}$ Agribusiness Study Program, Faculty of Agriculture, Udayana University \\ ${ }^{2}$ Centre of Excellence in Tourism, Udayana University \\ Corresponding Author: komangwidari4@gmail.com
}

\section{ARTICLE INFO}

Received

30 November 2019

Accepted

30 January 2020

Available online

01 March 2020

\section{ABSTRACT}

Belimbing Village Agrotourism is an agriculture-based sustainable agrotourism that has extensive terraced rice fields and stretches with a variety of natural potential around. Development of Belimbing Village Agrotourism is a tourism activity without changing the use and damage of agricultural land and can help the economy of the community in Belimbing Village. This study aims to determine the effect of farmers' knowledge, farmers' skills and farmers' attitudes on the satisfaction of Belimbing Village Agrotourism, the effect of tourists' satisfaction on visitor loyalty visiting Belimbing Village Agrotourism and Belimbing Village Agrotourism contribution to the welfare of the community in Belimbing Village. Data analysis method used is quantitative and qualitative analysis methods. The population in this study were farmers in Belimbing Village Agrotourism and tourists visiting Belimbing Village Agrotourism using 60 respondents, 30 people for farmers and 30 people for tourists. The model was designed using a Smart PLS-based Structural Equation Modeling (SEM) approach that was analyzed using a computer. The results showed that farmers' knowledge had a significant influence on tourists' satisfaction $(\mathrm{p}=0.031)$. Farmer skills have a significant influence on tourist satisfaction $(p=0.024)$. Farmer's attitude has a significant effect on tourist satisfaction $(p=0,000)$. Tourist satisfaction has a significant effect on tourist loyalty $(\mathrm{p}=0,000)$. The contribution of the Belimbing Village Agrotourism in terms of economy, environment and social has a positive impact on the welfare of the community in the Belimbing Village. Based on the results of the study, it is hoped that the Belimbing Village Agrotourism can maintain and improve farmers' knowledge, farmers' skills and farmers' attitudes, so that visiting tourists are satisfied and generate tourist loyalty to visit again.

Keywords: Role of Farmers, Agrotourism Development, Tourists' Satisfaction, Tourists' Loyalty 


\section{INTRODUCTION}

Indonesia is an agrarian country where the majority of the population works as farmers and has extensive land and biodiversity. The agricultural sector contributes greatly to the economy of the Indonesian population such as providing employment and a source of income for the majority of Indonesian people. However, the progress of development in the Indonesian agriculture sector until now has not been able to show satisfactory results when viewed from the level of welfare of farmers and their contribution to national income.

The decline in the agricultural sector in Bali is increasingly felt since the rapid development of the tourism sector as a mainstay sector to advance the economy of the Balinese people, but some of these benefits come out of the economic system in the form of tourism leakage. To minimize leakage suggested by Suryawardani, et.al. (2016) by utilizing local potential in developing businesses that support the development of Bali tourism without damaging nature and agriculture. Agriculture-based tourism such as Agrotourism is one of the efforts to develop natural potential that can be used as a source of income for the community. Belimbing Village Agrotourism is one of agriculture-based agrotourism that provides comfortable rural nature and has attractive and exotic tourism potential.

Agrotourism Development in Belimbing Village is tourism activities without converting land use and damaging agricultural land. This village has vast terraced rice fields and a variety of natural potentials that are around Agrotourism such as waterfalls that attract tourists to visit so that it becomes a benefit to generate large revenues for the Agrotourism. Sustainable Agrotourism in Belimbing Village is also one of the Agrotourism that utilizes natural resources optimally according to carrying capacity so that it does not cause environmental damage, respects the socio-culture of the local community, and ensures sustainable economic benefits thereby increasing the welfare of local people.

Based on the description above, research on the role of farmers in the development of the Belimbing Village Agrotourism and its influence on tourists' satisfaction and loyalty is important to find out the extent of the farmers' capacity in developing and managing Belimbing Village Agrotourism so that it has implications for tourists' satisfaction and loyalty. 
Formulation of the problems

Based on the background description above, the formulation of the problems are as follows:

1. What is the effect of knowledge, skills and attitudes of farmers on the satisfaction of Belimbing Village Agrotourism tourists?

2. What is the effect of tourists' satisfaction on visitor loyalty visiting the Belimbing Village Agrotourism?

3. What is the contribution of the Belimbing Village Agrotourism to the welfare of the community in the Belimbing Village?

\section{Research purposes}

The purpose of this research is to analyze:

1. The influence of farmers' knowledge, skills and attitudes on the satisfaction of Belimbing Village Agrotourism tourists

2. The influence of tourists' satisfaction on visitor loyalty visiting the Belimbing Village Agrotourism.

3. Contribution of Belimbing Village Agrotourism to the welfare of the community in Belimbing Village.

\section{METHODS}

\section{Research Location and Time}

This research was carried out in Belimbing Village Agrotourism, located in Belimbing Village, Pupuan Sub-District, Tabanan Regency from June to August 2019. The research began from the process of data collection until completion.

\section{Data Types and Sources}

The type of research data consisted of qualitative data consisting of an overview of the Belimbing Village Agrotourism and the organizational structure of the Belimbing Village Agrotourism Management Agency and quantitative data which included the number of farmers who played a role in the development of the Belimbing Village Agrotourism, the number of tourists visiting the Belimbing Village Agrotourism, area, type and the number of facilities available, the characteristics of farmers and tourists and the answers to the questionnaire statements obtained from tourists. Data sources used in this study were obtained from primary data sourced from direct respondents and secondary data not sourced from respondents. 


\section{Method of Collecting Data}

Data collection methods include observation, interviews using questionnaires and documentation as well as library research such as books, literature, scientific publications aimed at enrichment and data analysis.

\section{Population and Sample}

The research sampling is based on the requirements of the Smart-PLS analysis in which the requirements for the number of samples are between 30 to 100 . The number of research samples is 60 respondents with the consideration that the number has met the minimum requirements in the analysis using SEM with the Smart-PLS program. The sampling technique is done by accidental sampling technique that is the technique of determining samples based on chance. Sampling of respondents was done by 30 people for farmers and 30 people for tourists to the Belimbing Village Agrotourism.

\section{Research variables}

The variables used in this study are latent variables consisting of exogenous latent variables symbolized by $\mathrm{X}$ and endogenous latent variables symbolized by Y. Exogenous latent variables are influencing variables while endogenous variables are the affected variables. The http://ojs.unud.ac.id/index.php/eot number of latent variables in this study was 5 variables, consisting of 3 exogenous latent variables and 2 endogenous variables. Exogenous latent variables are farmer knowledge denoted by (PP), farmer skills (KP) and farmer's attitude (SP), while endogenous latent variables namely tourists' satisfaction are denoted by (KW) and Loyalty by (LY).

\section{Data analysis method}

a) Descriptive analysis

In this research, descriptive analysis is used to identify the characteristics of tourists and farmers. Descriptive analysis uses frequency tables, namely the presentation of data and information in the form of simple tables / figures with the help of the Microsoft Excel for Windows program to interpret the results of respondents' answers.

b) Validity and Reliability Test

The quality of the questionnaire in this study will be tested using the validity and reliability test by looking at the outer loading value in the analysis of structural equation models with the smart-PLS program.

c) Evaluation of the measurement model (outer model) and Evaluation of the structural model (inner model) 
Table 2.1

PLS Assessment Criteria

\begin{tabular}{|c|c|c|}
\hline No. & Criteria & Explanation \\
\hline \multicolumn{3}{|c|}{ Evaluation of Structural Models } \\
\hline 1 & $\begin{array}{l}\mathrm{R}^{2} \text { for } \\
\text { endogeno } \\
\text { us latent } \\
\text { variables }\end{array}$ & $\begin{array}{l}\text { The } \mathrm{R}^{2} \text { results for endogenous } \\
\text { latent variables in the structural } \\
\text { model indicate that the model is } \\
\text { good, moderate, and weak. }\end{array}$ \\
\hline 2 & $\begin{array}{l}\text { Estimated } \\
\text { path } \\
\text { coefficien } \\
t\end{array}$ & $\begin{array}{l}\text { The estimated value for the path } \\
\text { relationship in the structural model } \\
\text { must be significant. This significant } \\
\text { value can be obtained by the } \\
\text { bootstrapping procedure that also } \\
\text { produces a T-value. }\end{array}$ \\
\hline \multicolumn{3}{|c|}{ Evaluation of Reflexive Measurement Models } \\
\hline 1 & $\begin{array}{l}\text { Loading } \\
\text { Factor } \\
\text { (LF) }\end{array}$ & $\begin{array}{l}\text { The loading factor (lf) value must } \\
\text { be> } 0.7\end{array}$ \\
\hline 2 & $\begin{array}{l}\text { Composit } \\
\text { e } \\
\text { reliability }\end{array}$ & $\begin{array}{l}\text { Composite reliability measures } \\
\text { internal consistency and its value } \\
\text { must be }>0.6\end{array}$ \\
\hline 3 & $\begin{array}{l}\text { Average } \\
\text { Variance } \\
\text { Extracted } \\
\text { (AVE) }\end{array}$ & $\begin{array}{l}\text { The Average Variance Extracted } \\
\text { (AVE) value must be>0.5 }\end{array}$ \\
\hline 4 & $\begin{array}{l}\text { Discrimin } \\
\text { ant } \\
\text { validity }\end{array}$ & $\begin{array}{l}\text { The square root value of AVE must } \\
\text { be> correlation value between } \\
\text { latent variables }\end{array}$ \\
\hline 5 & $\begin{array}{l}\text { Cross } \\
\text { Loading }\end{array}$ & $\begin{array}{l}\text { Another measure of discriminant } \\
\text { validity. It is expected that each } \\
\text { indicator block has a higher loading } \\
\text { value for each latent variable } \\
\text { measured, compared to the } \\
\text { indicator for other latent variables }\end{array}$ \\
\hline
\end{tabular}

Source: Chin (1998, in Ghozali 2014)

\section{RESULTS AND DISCUSSION}

\section{Validity and Reliability Test}

\section{Validity test}

a) Convergent Validity

Convergent validity is an evaluation that is seen based on the correlation between the reflexive indicator score and the latent variable score. Convergent validity test is done by looking at the loading factor value of each indicator against latent variables. According to Chin in Suryawardani, 2018 the value of loading factors from 0.6 to 0.7 can still be accepted provided that the indicator is not the only indicator in the latent variable. The results showed that all factor-loading values for each indicator showed values above 0.7 . This means that all indicators are valid and feasible to use because they meet the criteria for convergent validity.

b) Discriminant Validity

Discriminant validity testing is carried out to ensure that each concept of each latent variable is different from other variables, by seeing the value of Cross Loading above 0.70 and the AVE value of each variable has a value above 0.5 (Ghozali, 2014). The results showed that the five latent variables had Cross Loading values above 0.70 and AVE above 0.5. This means that the discriminant validity test shows that all variables used in the study are said to be good or valid.

\section{Reliability Test}

Reliability testing can be done by looking at the Cronbach Alpha value and the reliability value of each contract. Variables are said to have high reliability if the Cronbach Alpha value exceeds 0.7 e-ISSN: 2407-392X. p-ISSN: 2541-0857 
and the composite reliability value is 0.70 . The results showed that all constructs measured in this study had a Cronbach's alpha value of all constructs 0.7 and composite reliability $>0.70$ so it could be said that all constructs were reliable or all indicators were correctly represented constructs that were built.

\section{Analysis of Structural Equation Models}

Confirmatory analysis in this study is intended to draw inference about the knowledge, skills and attitudes of farmers to tourists' satisfaction and form visitor loyalty, which is modeled through a structural equation model (SEM) involving 5 latent variables, namely farmers 'knowledge reflected by 10 indicators, farmers' skills by 9 indicators, farmers' attitudes by 12 indicators, tourists' satisfaction by 10 indicators, and loyalty by 4 indicators. Based on the model framework and hypotheses, the specification of structural equation models can be seen in Figure 5.1.

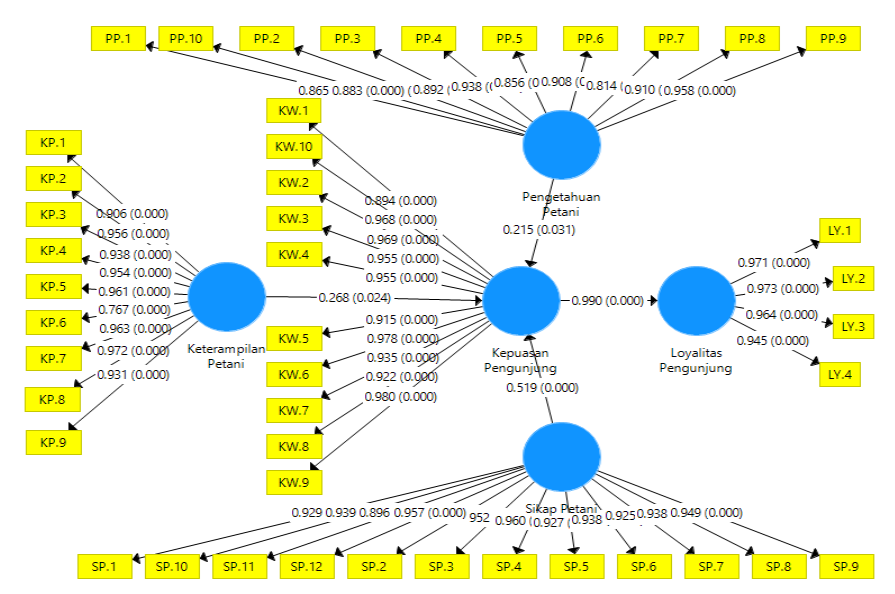

Figure 3.1

Structural Equation Modeling Output of the Role of Farmers in Belimbing Village Agrotourism Development and Its Effect on Tourists' Satisfaction and Loyalty

\section{Results of analysis of measurement models (outer models)}

Analysis of the measurement model or Outer model is a model to see the relationship between latent variables and their constituent indicators (Suryawardani, 2018). On indicators that are reflexive, estimator values can be seen from the outer loading value. The significance of this relationship is obtained through the bootstrapping process. In this study, using 3 exogenous variables, namely farmers' knowledge, farmers' skills and farmers' attitudes. Of the three variables that have the highest value, namely the attitudes of farmers, followed by the skills of farmers and the lowest is the knowledge of farmers while in endogenous variables there are 2 
latent variables namely tourists' satisfaction and loyalty.

a) Measurement Model Test Results (Outer Model) on Farmers' Knowledge Variable

The output of the measurement model on the attitude variable reflected by 12 indicators can be seen in Table 3.1.

Table 3.1Output Measurement Model of Farmers' Knowledge

\begin{tabular}{ccccc}
\hline Code & $\begin{array}{c}\text { Outer } \\
\text { Loading }\end{array}$ & $\begin{array}{c}\text { Standard } \\
\text { Error }\end{array}$ & T-Statistic \\
\hline PP.9 & 0.958 & 0.022 & 44.421 & $* *$ \\
PP.4 & 0.938 & 0.034 & 27.794 & $* *$ \\
PP.8 & 0.910 & 0.031 & 29.121 & $* *$ \\
PP.2 & 0.910 & 0.059 & 15.427 & $* *$ \\
PP.6 & 0.908 & 0.056 & 16.254 & $* *$ \\
PP.3 & 0.892 & 0.043 & 20.714 & $* *$ \\
PP.10 & 0.883 & 0.063 & 14.061 & $* *$ \\
PP.1 & 0.865 & 0.040 & 21.392 & $* *$ \\
PP.5 & 0.856 & 0.099 & 8,645 & $* *$ \\
PP.7 & 0.824 & 0.091 & 9.910 & $* *$ \\
\hline SOurce: & & & & \\
\hline
\end{tabular}

Source: Processed from primary data in 2019

b) Measurement Model Test Results (Outer Model) on Farmers' Skill Variable

The output of the measurement model on the farmers' skills variable reflected by 9 indicators which can be seen in Table 3.2.
Table 3.2

Output Measurement Model of Farmers'

\begin{tabular}{ccccc}
\multicolumn{5}{c}{ Skills } \\
\hline Code & $\begin{array}{c}\text { Outer } \\
\text { Loading }\end{array}$ & $\begin{array}{c}\text { Standard of } \\
\text { Error }\end{array}$ & $\begin{array}{c}\text { T- } \\
\text { Statistics }\end{array}$ \\
\hline KP.8 & 0.972 & 0.013 & 76.234 & $* *$ \\
KP.7 & 0.963 & 0.022 & 44.715 & $* *$ \\
KP.5 & 0.961 & 0.018 & 52.470 & $* *$ \\
KP.2 & 0.956 & 0.019 & 49.307 & $* *$ \\
KP.4 & 0.954 & 0.024 & 39.577 & $* *$ \\
KP.3 & 0.938 & 0.039 & 24.173 & $* *$ \\
KP.9 & 0.931 & 0.033 & 28.601 & $* *$ \\
KP.1 & 0.906 & 0.040 & 22.810 & $* *$ \\
KP.6 & 0.767 & 0.149 & 5.157 & $* *$
\end{tabular}

Source: Processed from primary data in 2019

c) Measurement Model Test Results (Outer Model) on Farmers' Attitude Variable

The output of the measurement model on the farmers' knowledge variable reflected by 10 indicators can be seen in Table 3.3.

Table 3.3

Output Measurement Model of Farmers' Attitude

\begin{tabular}{llccc}
\hline \multicolumn{1}{c}{ Code } & $\begin{array}{c}\text { Outer } \\
\text { Loading }\end{array}$ & $\begin{array}{c}\text { Standard } \\
\text { of Error }\end{array}$ & T-Statistic \\
\hline SP.2 & 0.971 & 0.012 & 78.593 & $* *$ \\
SP.4 & 0.960 & 0.016 & 58.245 & $* *$ \\
SP.12 & 0.957 & 0.020 & 48.053 & $* *$ \\
SP.3 & 0.952 & 0.025 & 37.884 & $* *$ \\
SP.9 & 0.949 & 0.029 & 32.631 & $* *$ \\
SP.10 & 0.939 & 0.031 & 30.365 & $* *$ \\
SP.8 & 0.938 & 0.026 & 35.899 & $* *$ \\
SP.6 & 0.938 & 0.025 & 38.183 & $* *$ \\
SP.1 & 0.929 & 0.032 & 28.601 & $* *$ \\
SP.5 & 0.957 & 0.040 & 22.953 & $* *$ \\
SP.7 & 0.925 & 0.031 & 29.828 & $* *$ \\
SP.11 & 0.896 & 0.044 & 20.460 & $* *$ \\
\hline Source Proces &
\end{tabular}

Source: Processed from primary data in 2019 
d) Measurement Model Test Results (Outer Model) on Tourists' Satisfaction Variables Output of the measurement model on tourists' satisfaction variable reflected by 10 indicators can be seen in Table 3.4

\section{Table 3.4}

Output Measurement Model of Tourists' Satisfaction

\begin{tabular}{lcccc}
\hline Code & $\begin{array}{c}\text { Outer } \\
\text { Loading }\end{array}$ & $\begin{array}{c}\text { Standard } \\
\text { of Error }\end{array}$ & $\begin{array}{c}\text { T- } \\
\text { Statistics }\end{array}$ & \\
\hline KW.9 & 0.980 & 0.011 & 86.256 & $* *$ \\
KW.6 & 0.978 & 0.014 & 70.134 & $* *$ \\
KW.2 & 0.969 & 0.019 & 50.020 & $* *$ \\
KW.10 & 0.968 & 0.022 & 43.079 & $* *$ \\
KW.4 & 0.955 & 0.032 & 29.984 & $* *$ \\
KW.3 & 0.955 & 0.023 & 41.384 & $* *$ \\
KW.7 & 0.935 & 0.034 & 27.534 & $* *$ \\
KW.8 & 0.922 & 0.043 & 21.284 & $* *$ \\
KW.5 & 0.915 & 0.034 & 27.241 & $* *$ \\
KW.1 & 0.894 & 0.049 & 18.426 & $* *$ \\
\hline Source & &
\end{tabular}

Source: Processed from primary data in 2019

e) Measurement Model Test Results (Outer Model) on Tourists' Loyalty Variables Output of the measurement model on visitor loyalty variables reflected by 4 indicators can be seen in Table 3.5.

Table 3.5

Output Model Measurement of Tourists' Loyalty

\begin{tabular}{ccccc}
\hline Code & $\begin{array}{c}\text { Outer } \\
\text { Loading }\end{array}$ & $\begin{array}{c}\text { Standard } \\
\text { of Error }\end{array}$ & $\begin{array}{c}\text { T- } \\
\text { Statistics }\end{array}$ \\
\hline LY.2 & 0.973 & 0.013 & 74.001 & $* *$ \\
LY.1 & 0.971 & 0.017 & 55.701 & $* *$ \\
LY.3 & 0.964 & 0.016 & 59.524 & $* *$ \\
LY.4 & 0.945 & 0.033 & 29.026 & $* *$ \\
\hline \multicolumn{5}{l}{ Source: Processed from primary data in }
\end{tabular}
2019

\section{Results of structural model analysis (inner model)}

Structural model analysis or inner model is used to see the relationship between variables that have the aim to test the relationship between one variable with another variable, both direct and indirect effects. The amount of direct effect with indirect effect is the total effect of exogenous variables on endogenous variables.

\section{Direct Influence Between Variables}

The test results of the direct influence of exogenous latent variables on endogenous variables indicate that the structural equation model that has been built is feasible to be used to test hypotheses in research. The complete significance test at the $5 \%$ level can be seen in Table 3.6.

Table 3.6

The Direct Effect of Exogenous Latent on

Endogenous Latent in the Inner Model

\begin{tabular}{|c|c|c|c|c|c|c|}
\hline $\begin{array}{l}\text { Hypo } \\
\text { thesis }\end{array}$ & $\begin{array}{l}\text { Exogeno } \\
\text { us } \\
\text { Variable } \\
\text { s }\end{array}$ & $\begin{array}{l}\text { Endoge } \\
\text { nous } \\
\text { Variabl } \\
\text { es }\end{array}$ & $\begin{array}{l}\text { Origi } \\
\text { nal } \\
\text { Samp } \\
\text { le }\end{array}$ & $\begin{array}{l}\text { Standard } \\
\text { Deviation }\end{array}$ & $\begin{array}{l}\text { T } \\
\text { Stat } \\
\text { istic }\end{array}$ & $\begin{array}{l}\mathbf{P} \\
\text { Valu } \\
\text { es }\end{array}$ \\
\hline H1 & $\begin{array}{l}\text { Farmers' } \\
\text { Knowled } \\
\text { ge } \rightarrow\end{array}$ & $\begin{array}{l}\text { Tourists' } \\
\text { Satisfact } \\
\text { ion }\end{array}$ & 0.215 & 0.100 & $\begin{array}{l}2.15 \\
8\end{array}$ & $\begin{array}{l}0.03 \\
1 *\end{array}$ \\
\hline $\mathrm{H} 2$ & $\begin{array}{l}\text { Farmers' } \\
\text { Skills } \\
\qquad \\
\end{array}$ & $\begin{array}{l}\text { Tourists' } \\
\text { Satisfact } \\
\text { ion }\end{array}$ & 0.268 & 0.118 & $\begin{array}{l}2.26 \\
7\end{array}$ & $\begin{array}{l}0.02 \\
4 *\end{array}$ \\
\hline $\mathrm{H} 3$ & $\begin{array}{l}\text { Farmers' } \\
\text { Attitude } \\
\rightarrow\end{array}$ & $\begin{array}{l}\text { Tourists' } \\
\text { Satisfact } \\
\text { ion }\end{array}$ & 0.519 & 0.088 & $\begin{array}{l}5.91 \\
7\end{array}$ & $\begin{array}{l}0.00 \\
0 * *\end{array}$ \\
\hline $\mathrm{H} 4$ & $\begin{array}{l}\text { Tourists' } \\
\text { Satisfacti } \\
\text { on } \rightarrow\end{array}$ & $\begin{array}{l}\text { Tourists' } \\
\text { loyalty }\end{array}$ & 0.990 & 0.003 & $\begin{array}{l}339 . \\
432\end{array}$ & $\begin{array}{l}0.00 \\
0 * *\end{array}$ \\
\hline
\end{tabular}

http://ojs.unud.ac.id/index.php/eot 
2. The indirect effect of exogenous variables on endogenous variables

The direct effect of the variable with a significant relationship according to the explanation in Table 3.7, there are also several paths in which an exogenous variable has an indirect effect on the corresponding endogenous variable through mediation of other latent variables. Effects that are more indirect can be seen in Table 3.7.

Table 3.7

The indirect effect of exogenous latent on endogenous latent in the inner model

\begin{tabular}{|c|c|c|c|c|c|c|}
\hline $\begin{array}{l}\text { Exoge } \\
\text { nous } \\
\text { Varia } \\
\text { bles }\end{array}$ & $\begin{array}{l}\text { Mediati } \\
\text { on } \\
\text { Variabl } \\
\text { e }\end{array}$ & $\begin{array}{l}\text { Endo } \\
\text { genou } \\
\text { s } \\
\text { Varia } \\
\text { bles }\end{array}$ & $\begin{array}{l}\text { Origi } \\
\text { nal } \\
\text { Sampl } \\
\text { e }\end{array}$ & $\begin{array}{l}\text { Stand } \\
\text { ard } \\
\text { Devia } \\
\text { tion }\end{array}$ & $\begin{array}{l}\text { T. } \\
\text { Stat } \\
\text { istic } \\
\text { S }\end{array}$ & $\begin{array}{l}\mathbf{P} \\
\text { Val } \\
\text { ues }\end{array}$ \\
\hline $\begin{array}{l}\text { Farme } \\
\text { rs' } \\
\text { Know } \\
\text { ledge } \\
\rightarrow\end{array}$ & $\begin{array}{l}\text { Tourists' } \\
\text { Satisfact } \\
\text { ion } \rightarrow\end{array}$ & $\begin{array}{l}\text { Touris } \\
\text { ts' } \\
\text { loyalt } \\
\mathrm{y}\end{array}$ & 0.265 & 0.112 & $\begin{array}{l}2.36 \\
9\end{array}$ & $\begin{array}{l}0.01 \\
8\end{array}$ \\
\hline $\begin{array}{l}\text { Keter } \\
\text { ampil } \\
\text { an } \\
\text { Petani } \\
\quad\end{array}$ & $\begin{array}{l}\text { Tourists' } \\
\text { Satisfact } \\
\text { ion } \rightarrow\end{array}$ & $\begin{array}{l}\text { Touris } \\
\text { ts' } \\
\text { loyalt } \\
\mathrm{y}\end{array}$ & 0.213 & 0.094 & $\begin{array}{l}2.26 \\
0\end{array}$ & $\begin{array}{l}0.02 \\
4\end{array}$ \\
\hline $\begin{array}{l}\text { Sikap } \\
\text { Petani }\end{array}$ & $\begin{array}{l}\text { Tourists' } \\
\text { Satisfact } \\
\text { ion } \rightarrow\end{array}$ & $\begin{array}{l}\text { Touris } \\
\text { ts' } \\
\text { loyalt } \\
y\end{array}$ & 0.514 & 0.091 & $\begin{array}{l}5.63 \\
3\end{array}$ & $\begin{array}{l}0.00 \\
0\end{array}$ \\
\hline
\end{tabular}

Source: Processed from primary data in 2019

\section{Contribution of Belimbing Village Agrotourism to Community Welfare}

The development of the Belimbing Village Agrotourism is expected to contribute to the welfare of the surrounding community. So far, revenue has been obtained through Agrotourism activities such as parking fees and tracking and cycling retribution around the Belimbing Village Agrotourism area. Belimbing Village Agrotourism also provides accommodations such as villas and restaurants that prioritize the community in Belimbing Village as workers or employees. Absorption of labor for the surrounding community has greatly helped to reduce unemployment rates in the Belimbing Village.

\section{CONCLUSIONS AND SUGGESTIONS}

\section{Conclusions}

Based on the analysis of the data that has been done, the following conclusions can be drawn:

1) The influence of farmers' knowledge, skills and attitudes on tourists' satisfaction:

a. Farmers' knowledge has a significant effect on the satisfaction of Belimbing Village Agrotourism tourists.

b. Farmers' skills have a significant effect on satisfaction

c. The attitude of the farmers has a significant effect on 
tourists' satisfaction at the Belimbing Village

Agrotourism.

2) Tourists' satisfaction has a significant effect on tourists' loyalty in the Belimbing Village Agrotourism.

3) Belimbing Village Agrotourism contributes to farm family income through distribution of tracking tickets, cycling and parking, is environmentally maintained and sustainable without damaging agricultural land and does not cause negative effects on the environment and the creation of good relations between management bodies, village heads and local governments, and between farmers with Agrotourism tourists.

\section{Suggestions}

Based on data analysis and conclusions that have been presented previously, this study proposes a number of suggestions as consideration for improving Belimbing Village Agrotourism, namely:

1) For the Belimbing Village Agrotourism, the results of the study showed that the variable of farmers' knowledge had the least influence on tourists' satisfaction, followed by the farmers' skills variable, then the farmers' attitude variable that had the highest influence, the farmers' skills and attitude in the Belimbing Village Agrotourism need to be maintained and one of them is to improve farmers' knowledge, one of which is the knowledge of farmers in promoting the Belimbing Village Agrotourism through social media so that it is better known among foreign and domestic tourists.

2) For further researchers, research should be carried out by developing research variables or adding indicators as measurements according to the conditions in the field and use different analysis tools.

\section{Acknowledgments}

The preparation of this thesis is inseparable from the guidance, assistance, and support from various parties, so that on this occasion I would like to express my gratitude to the Belimbing Village Agrotourism Management Agency for giving permission, facilities and assistance throughout the research process and thank farmers and tourists' respondents for their time. I also thank the undergraduate thesis e-ISSN: 2407-392X. p-ISSN: 2541-0857 
supervisor who has given me guidance so that the e-journal can be completed in a timely manner.

\section{REFERENCES}

Bungin, B.2011. "Quantitative Research Methodology ". Second Edition.Jakarta: Kencana.

Ghozali, I. 2014. Structural Equation Modeling Alternative Methods with Partial Least Square Applications. Semarang: Diponegoro University Publisher

Suryawardani, I G.A.O., and A.S Wiranatha.2018. Evaluation of Marketing Strategy of Sanur Village Festival Based on Tourists' Behaviour. Global Stochastics Analysis (GSA) Volume 5 Number 8 (2018), page 65-72. MUK Publication, ISSN 2248-94444.

Suryawardani, I.G.A.O., I K.G. Bendesa, M. Antara, D. Nursetyohasi, and A.S. Wiranatha.2016. Implementation of Social Accounting Matrix in Calculating Tourism Leakage of Accommodation in Bali. Internatinal Journal of Business and Economic Research, Volume 14 Number 12 (2016), page 9377-9405. Serial Publications PVT., LTD. New Delhi India. ISSN: 0972-7302. 